\title{
DETECTION OF THE HETEROZYGOUS CARRIER OF THE WILSON'S DISEASE GENE*
}

\author{
By IRMIN STERNLIEB, $\dagger$ ANATOL G. MORELL, CHARLES D. BAUER, BURTON \\ COMBES, SHIRLEY DE BOBES-STERNBERG AND I. HERBERT SCHEIN- \\ BERG WITH THE TECHNICAL ASSISTANCE OF JOSEPHINE C. BROSSEAU \\ (From the Department of Medicine, Albert Einstein College of Medicine and the Bronx \\ Municipal Hospital Center, N. Y.; the Department of Medicine, Kenmore Mercy \\ Hospital, Buffalo, N.Y.; the Department of Internal Medicine, University \\ of Texas Southwestern Medical School, Dallas, Texas; and the \\ Division of Biostatistics, Faculty of Medicine, Columbia \\ University, $N . Y$.).
}

(Submitted for publication August 1, 1960 ; accepted December 16, 1960)

In his original monograph, Wilson described the disease which is now named for him as ". . . familial, in the sense that frequently more than one member of a family is affected with it, but. . . not hereditary" (1). Subsequent studies (2-4) have indicated, however, that the disease is hereditary and is transmitted in autosomal recessive fashion by parents who never develop the illness. This implies both that Wilson's disease appears in those subjects who are homozygous for the "Wilson's disease gene" and that each parent of such a subject must be a heterozygote who possesses one of these abnormal genes and one of its normal alleles. We have chosen to designate the genotypes of patients, heterozygotes, and normal individuals, respectively, as cc, $\mathrm{Cc}$, and $\mathrm{CC}$.

The patient in whom Wilson's disease is, or will be, clinically manifest exhibits four abnormalities of copper metabolism: 1) a persistent deficiency or absence of normal ceruloplasmins, the blue, plasma copper-proteins $(3,5,6) ; 2)$ an increased concentration of loosely bound, non-ceruloplasmin copper in serum $(6,7) ; 3)$ an increased copper content of many organs and tissues (6, 8-13); and 4) an increased excretion of copper in

* Presented in part at the Fifty-first Annual Meeting of the American Society for Clinical Investigation, Atlantic City, N. J., May 4, 1959. This work was supported by grants from the National Institute of Arthritis and Metabolic Diseases of the United States Public Health Service (A-1059), and the Life Insurance Medical Research Fund (G-58-58).

$\dagger$ Most of this work was performed during the tenure of a Postdoctoral Research Fellowship, National Institutes of Health, Bethesda, Md.

$\ddagger$ Established Investigator, American Heart Association. the urine $(3,6,11,14)$. Although the mechanism is only partly understood, several investigators $(3,11,15,16)$ believe that the first two of these derangements lead to the third, the pathological effects of which constitute Wilson's disease.

The symptoms and physical signs of Wilson's disease never develop in the heterozygotes, and it is even unusual for them to manifest any of these four abnormalities. Considering these respectively, we find that 1 ) of 49 parents $^{1}$ of patients in whom serum ceruloplasmin concentrations were measured, directly or indirectly, only 10 showed a decreased concentration of this protein ; 2) of 4 parents in whom appropriate observations were made, only 1 showed an increased concentration of loosely bound, non-ceruloplasmin copper in serum $(7) ; 3$ ) there is no information concerning concentrations of tissue copper in parents of patients; and 4) parents have never been shown to exhibit hypercupriuria $(17,19)$.

Classical Mendelian concepts are not compatible with phenotypic manifestations of one recessive gene. However, recent reports indicate that the heterozygous carriers of some other recessive genes can be identified biochemically (22). Quantitative or qualitative changes, or both, in the protein whose synthesis the abnormal gene is assumed to govern may be demonstrable, as is true, for example, in individuals with sickle trait (23). Or there may be abnormal metabolism of elements or compounds, the usual metabolism of which is dependent on adequate concentrations of the nor-

1 Thirty parents were collected from the literature (17-21) and 19 were included in the present study (Table III). In our results only 1 of the 19 parents, M. D., showed a significant decrease in ceruloplasmin. 
mal protein (22). The work we are reporting suggests that measurements of the incorporation of a load of copper ${ }^{64}$ into ceruloplasmin can provide a fairly reliable means of distinguishing heterozygotes for the Wilson's disease gene from individuals who are homozygous for its normal allele.

\section{METHODS AND MATERIALS}

Test procedure. A much lower than normal incorporation of $\mathrm{Cu}^{64}$ into ceruloplasmin has been frequently demonstrated in patients with Wilson's disease $(18,24-28)$. Following the ingestion of cupric ${ }^{64}$ acetate (or sulfate) there is, within 1 to 2 hours, a sharp rise and fall in the serum concentration of $\mathrm{Cu}^{\text {s4 }}$ in all individuals. Normal individuals show a slow secondary rise in serum $\mathrm{Cu}^{64}$ concentration (Figure 1) due to $\mathrm{Cu}^{\text {os }}$ which has been incorporated into ceruloplasmin, whereas patients with Wilson's disease do not (Figure 2). When we found, by chance, that a parent of a patient with Wilson's disease showed almost no incorporation of $\mathrm{Cu}^{\text {es }}$ into ceruloplasmin, we were prompted to determine the degree of incorporation in other parents. In 1956, Bearn (29) suggested that a procedure similar to the one we have adopted might be useful in detecting heterozygous carriers of the Wilson's disease gene. In 1959, both SassKortsak, Glatt, Leeming and Muir (21) and ourselves (30) reported preliminary results of the kind presented here.

The test procedure was arbitrarily standardized: A dose of $2.0 \mathrm{mg}$ of copper as cupric ${ }^{\text {et }}$ acetate, or sulfate, with an activity of 0.5 to $2.0 \mathrm{mc}$, was administered in a cup of milk to each individual following a fast of 8 hours or more. The amount of $\mathrm{Cu}^{\text {o4 }}$ in $4.0 \mathrm{ml}$ of the subject's serum was determined in a well-type scintillation counter (DS-5-5, Nuclear, Chicago) 1, 2, 4, 24 and 48 hours

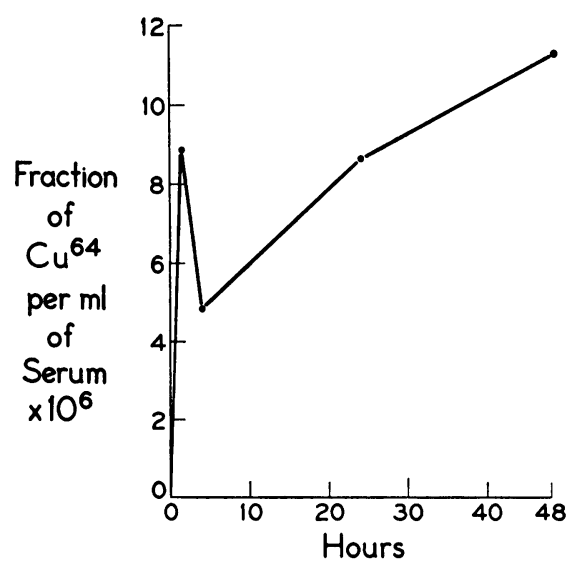

Fig. 1. The mean concentrations in SERUM OF $\mathrm{CU}^{\text {o4 }}$, EXPRESSED AS FRACTIONS OF THE ADMINISTERED DOSE PER MILLILITER, OF 19 CONTROL SUBJECTS AT VARIOUS TIMES AFTER THE INGESTION OF 2.0 MG OF CUPRIC ${ }^{\text {et }}$ ACETATE OR SULFATE.

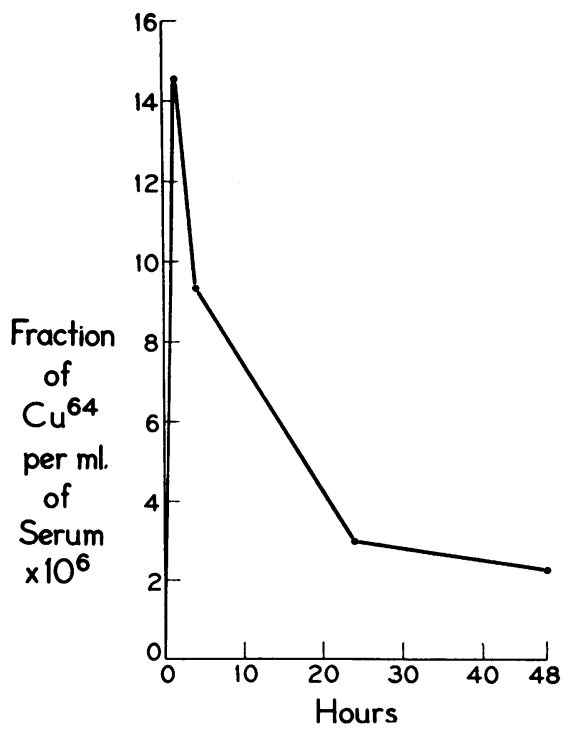

Fig. 2. The mean concentrations in Serum of $\mathrm{CU}^{\text {en }}$, EXPRESSED AS FRACTIONS OF THE ADMINISTERED DOSE PER MILLILITER, OF 7 PATIENTS WITH WILSON'S DISEASE AT VARIOUS TIMES AFTER THE INGESTION OF $2.0 \mathrm{MG}$ OF CUPRIC $^{\text {64 }}$ ACETATE OR SULFATE.

after ingestion. Measured radioactivity was corrected for physical decay, using a half-life of 12.8 hours (31) for $\mathrm{Cu}^{\mathrm{\theta}}$, and for background. The net corrected counts per minute per milliliter of serum were divided by the total number of counts per minute administered to the patient. These fractions, plotted against time, gave curves like those shown in Figures 1, 2 and 3.

From these curves we wanted to derive a measure of the incorporation of $\mathrm{Cu}^{\text {s4 }}$ into ceruloplasmin relative to the amount absorbed. We chose the ratio of the serum concentration of $\mathrm{Cu}^{84} 48$ hours after ingestion to this concentration at the initial peak. The 48-hour concentration represents essentially only $\mathrm{Cu}^{04}$ which has been incorporated into ceruloplasmin. This fact, demonstrated by other workers $(18,25,26)$, was confirmed by us. ${ }^{2}$ We have assumed the initial peak, taken as the higher of the 1- or 2-hour serum copper concentrations, to be a rough index of the amount of $\mathrm{Cu}^{64}$ absorbed from the gastrointestinal tract. Our measure, or test ratio, $\mathrm{R}$, then, can be written:

$$
\mathrm{R}=\frac{\left[\mathrm{Cu}^{64}\right]^{48^{\circ}}}{\left[\mathrm{Cu}^{64}\right]^{1-2}{ }^{\circ}}
$$

2 Non-ceruloplasmin-bound $\mathrm{Cu}^{\text {s4 }}$ can be quantitatively and specifically removed from $4.0 \mathrm{ml}$ of serum by the addition of $4.0 \mathrm{ml}$ of 0.9 per cent saline followed by $0.8 \mathrm{ml}$ of 0.2 per cent sodium diethyldithiocarbamate (DTC) in saline. The copper-DTC complex is adsorbed on a column of $100 \mathrm{mg}$ of activated charcoal (Norit) suspended in saline. By 48 hours after ingestion of $\mathrm{Cu}^{\text {st }}$ an average of only 4.3 per cent of $\mathrm{Cu}^{\text {et }}$ in the serum of 9 individuals could be removed by this technique. The $\mathrm{Cu}^{\text {at }}$ remaining in serum is enzymatically active ceruloplasmin-copper. 
where $\left[\mathrm{Cu}^{64}\right]$ represents the $\mathrm{Cu}^{\text {et }}$ concentration of serum. Obviously, the greater the test ratio, the greater is the incorporation of $\mathrm{Cu}^{\text {s4 }}$ into ceruloplasmin relative to the amount absorbed.

Total serum copper was determined, on samples taken with copper-free precautions, by means of wet-ashing and dicyclohexanoneoxalyldihydrazone (32). Serum ceruloplasmin concentrations (32) were measured in each individual on the first and third day of the study, to determine if a change in the concentration of the protein had occurred. Each subject's blood was typed for the $\mathrm{ABO}, \mathrm{M}, \mathrm{N}$, and $\mathrm{Rh}(\mathrm{C}, \mathrm{D}, \mathrm{E}, \mathrm{c})$ groups.

$C u^{84}$. Radioactive $\mathrm{Cu}^{64}$ was supplied as a solution of cupric $^{64}$ acetate by Abbott Laboratories, Oak Ridge, Tenn., or as metallic copper ${ }^{84}$ by the Brookhaven National Laboratory, Upton, N. Y.

Subjects. Nineteen individuals, without family histories of Wilson's disease, were the control subjects. From estimates of gene frequency (3) each control subject probably had less than a 1 per cent chance of being, in fact, heterozygous for the Wilson's disease gene (Group I).

Seven patients with Wilson's disease were included in the study and each, by definition, possessed two Wilson's disease genes (Group II).

Nineteen parents of patients with Wilson's disease, whose blood groups were consistent with biological parentage, were the test subjects who were heterozygous for the Wilson's disease gene (Group III).

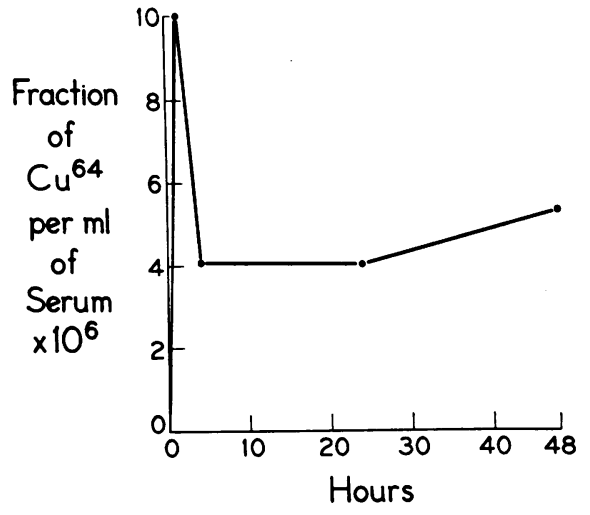

Fig. 3. The mean concentrations in Serum of $\mathrm{Cu}^{64}$, EXPRESSED AS FRACTIONS OF THE ADMINISTERED DOSE PER MILLILITER, OF 19 KNOWN HETEROZYGOTES (PARENTS OF patients With Wilson's disease) at various times AFTER THE INGESTION OF 2.0 MG. OF CUPRIC ${ }^{\text {bA }}$ ACETATE OR SULFATE.

Forty-five relatives of patients (unaffected siblings, half-siblings, aunts, uncles, grandparents, cousins and half-nieces) (Group IV) served as subjects each with an $a$ priori probability of either 25,50 or $66 \% 3$ per cent of being heterozygous for the Wilson's disease gene, depending on the genetic model.

TABLE $I^{*}$

Concentrations of ceruloplasmin, total copper and radioactive copper ${ }^{64}$ in the sera of 19 control subjects

\begin{tabular}{|c|c|c|c|c|c|c|c|c|c|c|}
\hline \multirow[b]{2}{*}{ Subject } & \multirow[b]{2}{*}{ Sex } & \multirow[b]{2}{*}{ Age } & \multirow{2}{*}{$\begin{array}{l}\text { Cerulo- } \\
\text { plasmin }\end{array}$} & \multirow{2}{*}{$\begin{array}{l}\text { Total } \\
\text { copper }\end{array}$} & \multicolumn{5}{|c|}{ Fraction of administered dose of $\mathrm{Cu}^{64} / \mathrm{ml} \times 10^{6}$} & \multirow{2}{*}{$\frac{\left[\mathrm{Cu}^{64}\right]^{48^{\circ}}}{\left[\mathrm{Cu}^{64}\right]^{1-2}}$} \\
\hline & & & & & $1 \mathrm{hr}$ & $2 \mathrm{hrs}$ & $4 \mathrm{hrs}$ & $24 \mathrm{hrs}$ & $48 \mathrm{hrs}$ & \\
\hline & & & $\mathrm{mg} / 100 \mathrm{ml}$ & $\mu \mathrm{g} / 100 \mathrm{ml}$ & & & & & & \\
\hline F.K. & $\mathbf{M}$ & 41 & 33.1 & & 13.661 & 8.116 & 6.077 & 8.800 & 11.232 & 0.822 \\
\hline J.M. & $\mathbf{M}$ & 21 & 26.9 & 107 & 13.938 & 14.714 & 8.594 & 11.172 & 12.302 & 0.836 \\
\hline H.G. & $\mathbf{M I}$ & 65 & 28.6 & 128 & 12.170 & 9.141 & 5.782 & 10.389 & 10.997 & 0.904 \\
\hline N.D. & $\mathbf{M}$ & 49 & 26.6 & 135 & 12.449 & 13.015 & 8.571 & 10.230 & 12.402 & 0.953 \\
\hline E.D. & $\mathrm{F}$ & 45 & 60.1 & 258 & 12.028 & 9.833 & 4.956 & 10.081 & 12.406 & 1.031 \\
\hline P.M. & M & 64 & 38.3 & 128 & 0.557 & 3.013 & 1.717 & 2.571 & 3.129 & 1.038 \\
\hline P.N. & $\mathrm{F}$ & 39 & 26.7 & & 7.635 & 7.616 & 2.852 & 4.854 & 8.165 & 1.069 \\
\hline W.K. & M & 67 & 29.0 & 134 & 7.708 & 4.227 & 3.532 & 6.895 & 8.473 & 1.099 \\
\hline A.Mo. & $\mathrm{F}$ & 47 & 38.2 & 136 & 15.152 & 14.762 & 7.571 & 13.829 & 17.381 & 1.147 \\
\hline J.H. & M & 42 & 48.9 & 151 & 7.581 & 8.729 & 4.430 & 8.355 & 10.208 & 1.169 \\
\hline $\mathrm{J} . \mathrm{O}$. & $\mathrm{F}$ & 45 & 53.4 & & 12.612 & 16.599 & 8.089 & 14.187 & 21.005 & 1.265 \\
\hline D.Wo. & $\mathrm{F}$ & 48 & 29.2 & 143 & 12.013 & 13.951 & 7.402 & 11.280 & 15.865 & 1.321 \\
\hline M.W. & $\mathrm{M}$ & 64 & 46.9 & 174 & 3.255 & 3.821 & 2.427 & 5.062 & 6.063 & 1.587 \\
\hline N.G. & $\mathbf{M}$ & 55 & 45.5 & 186 & 2.600 & 2.236 & 1.679 & 3.517 & 5.069 & 1.950 \\
\hline J.Q. & $\mathbf{M}$ & 74 & 34.5 & 136 & 3.115 & 3.304 & 2.946 & 4.396 & 6.613 & 2.001 \\
\hline J.C. & $\mathrm{F}$ & 51 & 34.3 & 177 & 4.212 & 7.806 & 5.825 & 12.916 & 16.879 & 2.162 \\
\hline A.M. & $\mathrm{F}$ & 69 & 40.5 & 155 & 2.320 & 2.908 & 2.626 & 5.042 & 6.739 & 2.317 \\
\hline A.L. & $\mathrm{F}$ & 66 & 43.2 & 220 & 2.620 & 4.936 & 3.316 & 9.790 & 13.023 & 2.638 \\
\hline S.F. & $\mathrm{F}$ & 54 & 58.2 & & 3.068 & 5.076 & 4.165 & 10.868 & 15.141 & 2.983 \\
\hline Mean & & & 39.06 & 157.9 & & & & & & \\
\hline SD & & & 10.74 & 39.6 & & & & & & \\
\hline \multirow{3}{*}{\multicolumn{10}{|c|}{$\begin{array}{l}\text { Antilog (mean } \log R) \\
\text { Antilog (mean } \log R+S D \log R) \\
\text { Antilog (mean } \log R-S D \log R)\end{array}$}} & 1.372 \\
\hline & & & & & & & & & & 2.057 \\
\hline & & & & & & & & & & 0.915 \\
\hline
\end{tabular}

* The italicized numbers represent the peak concentrations of $\mathrm{Cu}^{64}$ at 1 or 2 hours after feeding. 
TABLE II *

Concentrations of ceruloplasmin, total copper and radioactive copper ${ }^{64}$ in the sera of 7 patients with Wilson's disease

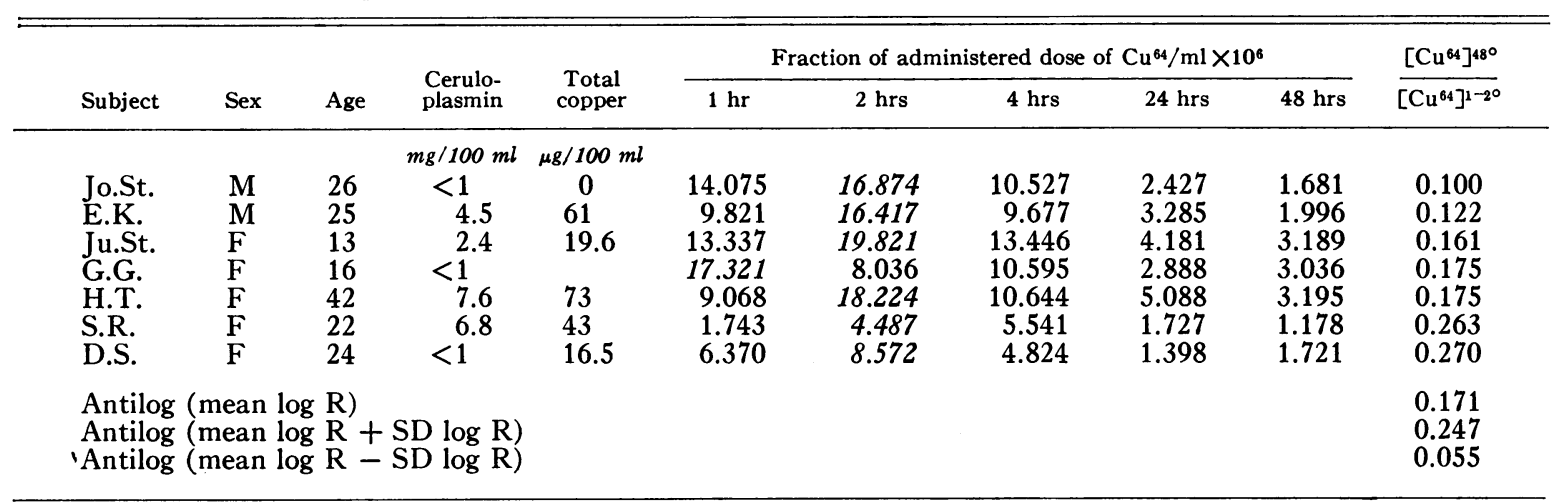

* The italicized numbers represent the peak concentrations of $\mathrm{Cu}^{64}$ at 1 or 2 hours after feeding.

\section{RESULTS}

Tables I, II, III and IV list the values measured in the individuals of the various groups, and the calculated test ratios. Ceruloplasmin concentrations are mean values of the determinations made on the first and third days of the experiment, the differences between which were never greater than the approximately 10 per cent difference be- tween duplicate determinations. Copper concentrations are means of triplicate measurements made on the first day.

The values for the concentrations of serum ceruloplasmin and copper for the control subjects (Group I), are somewhat higher than normal values. Concentrations of these substances are known to be elevated in a variety of clinical conditions (33), and, since these subjects were almost

TABLE III *

Concentrations of ceruloplasmin, total copper and radioactive copper ${ }^{64}$ in the sera of 19 parents of patients with Wilson's disease

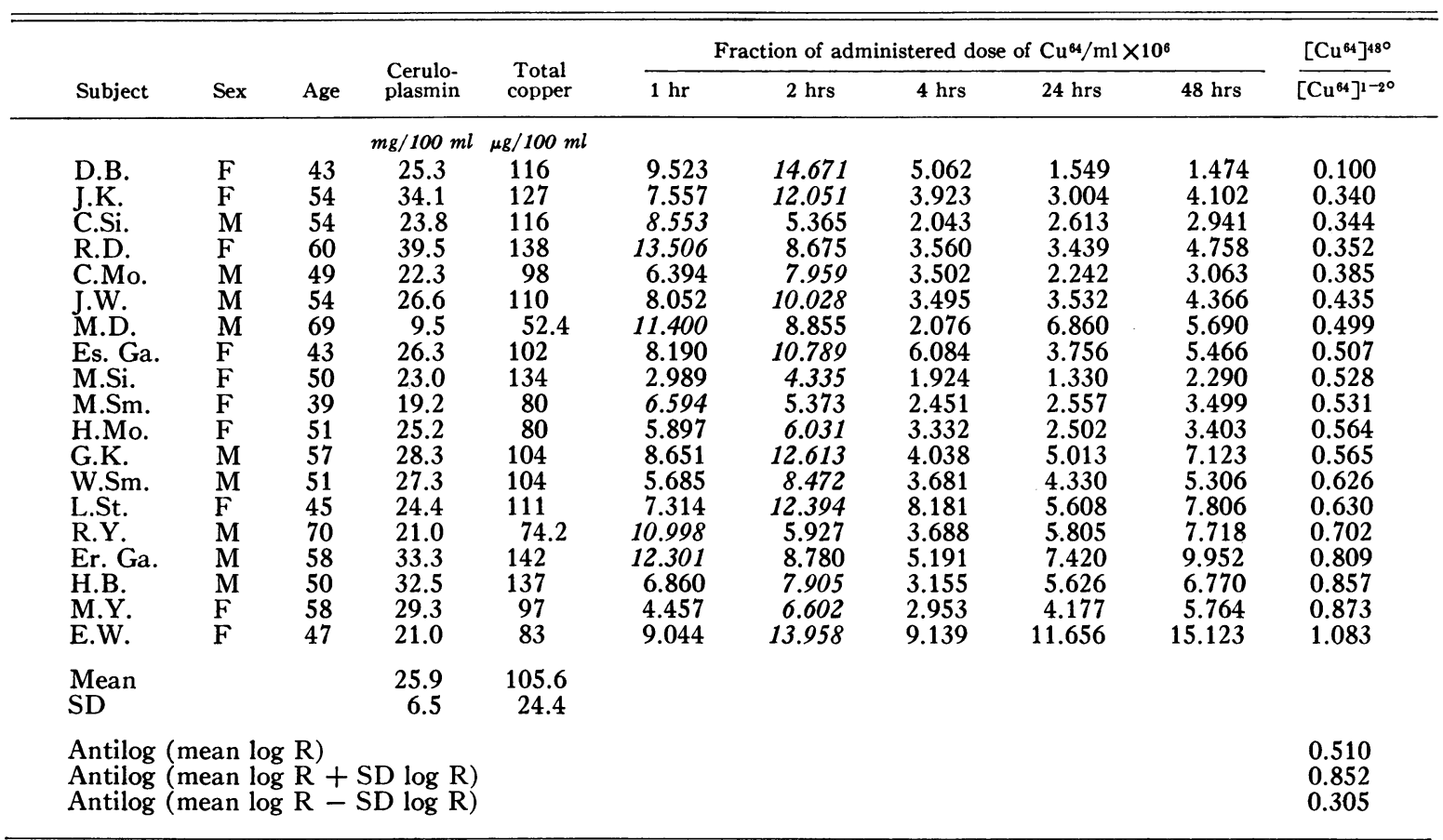

* The italicized numbers represent the peak concentrations of $\mathrm{Cu}^{64}$ at 1 or 2 hours after feeding. 
TABLE IV *

Concentrations of ceruloplasmin, total copper and radioactive copper ${ }^{64}$ in the sera of asymptomatic relatives (exclusive of parents) of patients with Wilson's disease (HLD)

\begin{tabular}{|c|c|c|c|c|c|c|c|c|c|c|}
\hline \multirow[b]{2}{*}{ Subject } & \multirow[b]{2}{*}{ Sex } & \multirow[b]{2}{*}{ Age } & \multirow{2}{*}{$\begin{array}{l}\text { Cerulo- } \\
\text { plasmin }\end{array}$} & \multirow{2}{*}{$\begin{array}{l}\text { Total } \\
\text { copper }\end{array}$} & \multicolumn{5}{|c|}{ Fraction of administered dose of $\mathrm{Cu}^{64} / \mathrm{ml} \times 10^{6}$} & \multirow{2}{*}{$\frac{\left[\mathrm{Cu}^{64}\right]^{48^{\circ}}}{\left[\mathrm{Cu}^{64}\right]^{1-2^{\circ}}}$} \\
\hline & & & & & $1 \mathrm{hr}$ & $2 \mathrm{hrs}$ & $4 \mathrm{hrs}$ & $24 \mathrm{hrs}$ & $48 \mathrm{hrs}$ & \\
\hline \multicolumn{11}{|c|}{ Unaffected siblings } \\
\hline $\begin{array}{l}\text { B.St. } \\
\text { R.St. } \\
\text { F.Sm. } \\
\text { T.Si. } \\
\text { L.Sm.Jr. } \\
\text { Jn.St. } \\
\text { J.D. } \\
\text { R.L.Y. } \\
\text { S.Sm. } \\
\text { W.Sm.Jr. } \\
\text { M.St. } \\
\text { C.St. } \\
\text { D.C. }\end{array}$ & $\begin{array}{l}\mathrm{M} \\
\mathrm{M} \\
\mathrm{M} \\
\mathrm{M} \\
\mathrm{M} \\
\mathrm{F} \\
\mathrm{F} \\
\mathrm{M} \\
\mathrm{M} \\
\mathrm{M} \\
\mathrm{F} \\
\mathrm{F} \\
\mathrm{F}\end{array}$ & $\begin{array}{r}11 \\
27 \\
15 \\
16 \\
14 \\
14 \\
42 \\
18 \\
6 \\
8 \\
16 \\
20 \\
35\end{array}$ & $\begin{array}{l}22.4 \\
19.4 \\
15.5 \\
18.1 \\
18.7 \\
22.1 \\
37.8 \\
19.9 \\
25.4 \\
26.2 \\
26.5 \\
24.6 \\
24.1\end{array}$ & $\begin{array}{r}91 \\
111 \\
71 \\
58 \\
70 \\
72 \\
119 \\
62 \\
100 \\
105 \\
91 \\
90 \\
97\end{array}$ & $\begin{array}{r}6.012 \\
9.687 \\
11.625 \\
3.290 \\
1.153 \\
11.705 \\
13.830 \\
12.114 \\
9.615 \\
9.115 \\
2.879 \\
6.090 \\
6.386\end{array}$ & $\begin{array}{r}6.685 \\
2.401 \\
6.805 \\
5.035 \\
8.223 \\
10.672 \\
7.990 \\
8.886 \\
11.174 \\
10.606 \\
4.419 \\
8.980 \\
6.646\end{array}$ & $\begin{array}{l}8.249 \\
2.673 \\
2.436 \\
2.885 \\
2.975 \\
4.229 \\
3.237 \\
4.172 \\
4.074 \\
3.521 \\
2.842 \\
3.786 \\
5.370\end{array}$ & $\begin{array}{l}1.113 \\
1.247 \\
2.158 \\
1.202 \\
2.561 \\
3.213 \\
3.856 \\
4.469 \\
4.992 \\
4.623 \\
4.133 \\
5.711 \\
8.165\end{array}$ & $\begin{array}{r}0.718 \\
1.690 \\
2.739 \\
1.367 \\
2.595 \\
4.060 \\
5.370 \\
5.210 \\
6.439 \\
7.207 \\
4.000 \\
8.194 \\
10.260\end{array}$ & $\begin{array}{l}0.107 \\
0.174 \\
0.236 \\
0.271 \\
0.315 \\
0.347 \\
0.388 \\
0.430 \\
0.576 \\
0.679 \\
0.905 \\
0.912 \\
1.544\end{array}$ \\
\hline \multicolumn{11}{|l|}{ Half-siblings } \\
\hline $\begin{array}{l}\text { M.DP. } \\
\text { P.A. } \\
\text { C.Sm. }\end{array}$ & $\begin{array}{l}F \\
F \\
M\end{array}$ & $\begin{array}{l}30 \\
25 \\
23\end{array}$ & $\begin{array}{l}27.2 \\
29.3 \\
26.7\end{array}$ & $\begin{array}{l}115 \\
129 \\
112\end{array}$ & $\begin{array}{r}12.803 \\
7.296 \\
3.508\end{array}$ & $\begin{array}{r}18.169 \\
9.192 \\
3.929\end{array}$ & $\begin{array}{l}8.933 \\
4.192 \\
3.325\end{array}$ & $\begin{array}{r}11.332 \\
7.805 \\
4.446\end{array}$ & $\begin{array}{r}14.516 \\
10.480 \\
5.654\end{array}$ & $\begin{array}{l}0.799 \\
1.140 \\
1.439\end{array}$ \\
\hline \multicolumn{11}{|c|}{ Aunts and uncles of HLD patients } \\
\hline $\begin{array}{l}\text { E.P. } \\
\text { T.Q. } \\
\text { P.S.H.Mo. } \\
\text { J.Q.Sr. } \\
\text { L.Sm.Sr. } \\
\text { E.Ro. } \\
\text { H.P. } \\
\text { St.Q. } \\
\text { F.Q. } \\
\text { M.EV. } \\
\text { F.T. }\end{array}$ & $\begin{array}{l}\mathrm{M} \\
\mathrm{M} \\
\mathrm{M} \\
\mathrm{M} \\
\mathrm{M} \\
\mathrm{F} \\
\mathrm{M} \\
\mathrm{M} \\
\mathrm{M} \\
\mathrm{F} \\
\mathrm{F}\end{array}$ & $\begin{array}{l}44 \\
44 \\
43 \\
44 \\
54 \\
50 \\
39 \\
40 \\
46 \\
45 \\
55\end{array}$ & $\begin{array}{l}10.3 \\
13.4 \\
21.5 \\
16.2 \\
21.4 \\
25.1 \\
26.9 \\
25.6 \\
29.1 \\
29.4 \\
31.3\end{array}$ & $\begin{array}{r}50 \\
61 \\
84 \\
68 \\
86 \\
108 \\
122 \\
110 \\
113 \\
166 \\
106\end{array}$ & $\begin{array}{r}8.082 \\
8.018 \\
9.348 \\
9.158 \\
15,346 \\
5.425 \\
11.779 \\
8.531 \\
11.492 \\
10.071 \\
4.885\end{array}$ & $\begin{array}{r}7.927 \\
12.700 \\
8.650 \\
5.682 \\
10.292 \\
6.531 \\
7.607 \\
14.650 \\
7.208 \\
11.763 \\
6.228\end{array}$ & $\begin{array}{l}3.667 \\
6.355 \\
3.095 \\
2.684 \\
6.484 \\
3.055 \\
4.793 \\
7.863 \\
5.487 \\
8.936 \\
4.384\end{array}$ & $\begin{array}{r}0.825 \\
3.657 \\
2.007 \\
4.107 \\
7.975 \\
3.083 \\
6.636 \\
9.632 \\
10.189 \\
13.380 \\
8.560\end{array}$ & $\begin{array}{r}0.116 \\
3.992 \\
3.058 \\
4.144 \\
8.641 \\
4.488 \\
8.198 \\
12.594 \\
11.593 \\
16.195 \\
11.235\end{array}$ & $\begin{array}{l}0.143 \\
0.314 \\
0.327 \\
0.452 \\
0.563 \\
0.768 \\
0.696 \\
0.859 \\
1.009 \\
1.377 \\
1.804\end{array}$ \\
\hline \multicolumn{11}{|c|}{ Cousins of HLD patients } \\
\hline $\begin{array}{l}\text { N.Mo. } \\
\text { T.Mo. } \\
\text { C.Mo.Jr. } \\
\text { Sa.Q. } \\
\text { J.Q.Jr. } \\
\text { P.Mo.Jr. } \\
\text { M.Ro. } \\
\text { D.Mo. } \\
\text { M.Q. } \\
\text { J.Ro. }\end{array}$ & $\begin{array}{l}\mathrm{F} \\
\mathrm{M} \\
\mathrm{M} \\
\mathrm{F} \\
\mathrm{M} \\
\mathrm{M} \\
\mathrm{M} \\
\mathrm{M} \\
\mathrm{F} \\
\mathrm{M}\end{array}$ & $\begin{array}{r}15 \\
18 \\
9 \\
19 \\
14 \\
10 \\
20 \\
20 \\
20 \\
18\end{array}$ & $\begin{array}{l}21.2 \\
15.4 \\
23.8 \\
19.9 \\
16.2 \\
28.3 \\
22.9 \\
30.9 \\
21.7 \\
23.9\end{array}$ & $\begin{array}{c}86 \\
63 \\
90 \\
90 \\
68 \\
134 \\
75.5 \\
101 \\
97 \\
72.7\end{array}$ & $\begin{array}{r}10.768 \\
7.988 \\
7.319 \\
10.570 \\
12.242 \\
14.614 \\
8.040 \\
7.599 \\
9.485 \\
5.595\end{array}$ & $\begin{array}{r}12.768 \\
9.465 \\
13.566 \\
9.271 \\
9.401 \\
11.176 \\
9.140 \\
12.913 \\
12.427 \\
6.978\end{array}$ & $\begin{array}{l}4.443 \\
3.380 \\
5.899 \\
4.666 \\
5.775 \\
5.325 \\
4.974 \\
6.149 \\
6.232 \\
6.814\end{array}$ & $\begin{array}{l}2.118 \\
1.885 \\
2.426 \\
3.695 \\
3.347 \\
4.875 \\
3.755 \\
8.355 \\
7.638 \\
7.300\end{array}$ & $\begin{array}{r}2.946 \\
2.220 \\
3.704 \\
4.803 \\
5.823 \\
7.011 \\
4.936 \\
9.570 \\
10.535 \\
8.250\end{array}$ & $\begin{array}{l}0.231 \\
0.235 \\
0.273 \\
0.454 \\
0.475 \\
0.480 \\
0.540 \\
0.741 \\
0.848 \\
1.182\end{array}$ \\
\hline \multicolumn{11}{|c|}{ Half-nieces of HLD patients } \\
\hline $\begin{array}{l}\text { ME.DP. } \\
\text { C.DP. }\end{array}$ & $\mathrm{F}$ & $\begin{array}{l}9 \\
7\end{array}$ & $\begin{array}{l}37.8 \\
41.7\end{array}$ & $\begin{array}{l}167 \\
200\end{array}$ & $\begin{array}{l}10.698 \\
16.089\end{array}$ & $\begin{array}{l}16.645 \\
12.084\end{array}$ & $\begin{array}{l}7.862 \\
6.808\end{array}$ & $\begin{array}{l}14.802 \\
13.866\end{array}$ & $\begin{array}{l}18.229 \\
21.111\end{array}$ & $\begin{array}{l}1.095 \\
1.312\end{array}$ \\
\hline \multicolumn{11}{|c|}{ Grandparents of HLD patients } \\
\hline $\begin{array}{l}\text { E.O'N. } \\
\text { G.W. } \\
\text { W.J.W. } \\
\text { E.S. } \\
\text { J.O'N. } \\
\text { E.Q. }\end{array}$ & $\begin{array}{l}F \\
F \\
M \\
F \\
M \\
F\end{array}$ & $\begin{array}{l}76 \\
80 \\
83 \\
75 \\
82 \\
70\end{array}$ & $\begin{array}{l}23.9 \\
33.0 \\
30.0 \\
24.6 \\
41.4 \\
37.2\end{array}$ & $\begin{array}{l}119 \\
123 \\
117 \\
128 \\
168 \\
132\end{array}$ & $\begin{array}{l}7.037 \\
2.184 \\
3.397 \\
6.221 \\
5.109 \\
7.512\end{array}$ & $\begin{array}{r}13.244 \\
4.017 \\
4.821 \\
7.146 \\
5.921 \\
5.307\end{array}$ & $\begin{array}{l}8.304 \\
2.736 \\
3.065 \\
5.028 \\
3.857 \\
4.392\end{array}$ & $\begin{array}{l}9.891 \\
3.382 \\
4.931 \\
7.014 \\
5.865 \\
8.176\end{array}$ & $\begin{array}{r}11.865 \\
4.387 \\
5.424 \\
8.618 \\
7.665 \\
10.893\end{array}$ & $\begin{array}{l}0.896 \\
1.090 \\
1.125 \\
1.206 \\
1.295 \\
1.450\end{array}$ \\
\hline
\end{tabular}

* The italicized numbers represent the peak concentrations of $\mathrm{Cu}^{64}$ at 1 or 2 hours after feeding. 


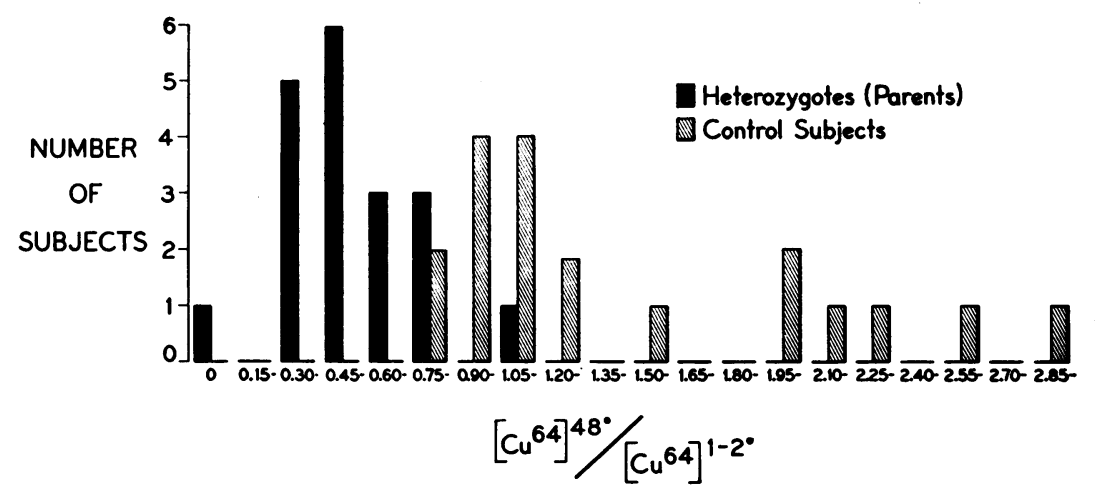

Fig. 4. The distribution of test ratios in 19 control subjects and 19 HETEROZYGOTES.

all hospitalized patients, it is likely that such nonspecific elevations account for the high values found.

In all control subjects, for each sampling time, the mean fraction of the administered dose of $\mathrm{Cu}^{64}$ present in $1 \mathrm{ml}$ of serum was calculated from the individual determinations. A curve through these five means, observed at $1,2,4,24$ and 48 hours after administration of $\mathrm{Cu}^{64}$, is shown in Figure 1. Similarly computed curves are given for the patients (Group II) and heterozygotes (Group III) in Figures 2 and 3, respectively. No "mean curve" was made for Group IV because of the heterogeneity of this group.

\section{DISCUSSION}

A. Differentiation of the genotypes $c c, C c$ and $C C$. The subject, cc, who inherits two Wilson's disease genes can almost always be detected when first seen by the physician (16). He may already have developed the hepatic or neurologic findings and Kayser-Fleischer rings which are characteristic of Wilson's disease. If so, one can be certain of the diagnosis without even determining if other clinical or biochemical characteristics of the disease are present. However, if the subject is asymptomatic, the demonstration of 1) a serum concentration of normal ceruloplasmins which is persistently less than $15 \mathrm{mg}$ per $100 \mathrm{ml}(5,34$, $35)$; 2) more than $30 \mu \mathrm{g}$ of non-ceruloplasmin copper per $100 \mathrm{ml}$ of serum $(6,7) ; 3)$ a concentration of hepatic copper of more than $150 \mu \mathrm{g}$ per $\mathrm{g}$ of dry liver (12); or 4) the urinary excretion of more than $100 \mu \mathrm{g}$ of copper in 24 hours $(3,6,11$, $14,33)$ makes it highly probable that he has Wil- son's disease which will eventually be manifest clinically.

The sensitivity and specificity of our test in distinguishing the heterozygote, $\mathrm{Cc}$, from the homozygously normal individual, $\mathrm{CC}$, was estimated by comparing the test ratios of Group I (control subjects) with those of Group III (heterozygotes). It was apparent from inspection that the values of $R$ in the control subjects were not normally distributed (Figure 4). However, $\log \mathrm{R}$ may be normally distributed, judging from our sample, giving equal variance for the distribution in both heterozygous and control groups. Table I shows that antilog (mean $\log \mathrm{R}$ ) $=1.372$ and gives the standard deviation for this geometric mean in the 19 control subjects. Table III gives antilog (mean $\log \mathrm{R}$ ) $=0.510$ for the 19 heterozygotes. Statistical analysis (36), applied to the values for $\log R$, indicates that if an individual has an $\mathrm{R}($ not $\log \mathrm{R}$ ) of less than 0.559 he is probably a heterozygote since, with 99 per cent confidence, 10 per cent or less of all homozygously normal individuals have ratios of less than 0.559 . If an individual has $\mathrm{R}$ greater than 1.253 he is probably homozygously normal since 10 per cent or less of the heterozygote population has ratios greater than 1.253 , with 99 per cent certainty. If $\mathrm{R}$ falls between 0.559 and 1.253 the individual cannot be classified by this test, since there is too large a risk of error.

The results of the test we have described must obviously be dependent, to some extent at least, on the concentration of ceruloplasmin in the subject's serum. Two questions may, therefore, be asked : 1) how closely are the serum ceruloplasmin concentration and $\mathrm{R}$ correlated; and 2) does the 
ratio discriminate better between heterozygotes and homozygously normal individuals than the ceruloplasmin concentration? To answer these questions correlation coefficients were calculated for ceruloplasmin concentration, and $\log \mathrm{R}$, for Groups I and III and found to be 0.42 and -0.04 , respectively. Neither of these is significantly different from zero. A plot of the concentration of ceruloplasmin versus $\log \mathrm{R}$ for the individuals in Group IV, however, suggested a positive correlation, and a correlation coefficient of 0.62 , significantly different from zero, was calculated for the combined data of Groups I, III and IV. Consequently, the measurements of ceruloplasmin concentration were analyzed by the same statistical methods used for $\log \mathrm{R}$ to determine how well these concentrations could differentiate heterozygous from normal individuals. The results were as follows: if a healthy individual has a ceruloplasmin concentration of less than $21.7 \mathrm{mg}$ per $100 \mathrm{ml}$ he is probably a heterozygote (if, of course, he is not homozygously abnormal, cc) since, with 99 per cent certainty, 10 per cent or less of the normal population has a concentration of below $21.7 \mathrm{mg}$ per $100 \mathrm{ml}$. If a healthy individual has a ceruloplasmin concentration of more than 43.2 $\mathrm{mg}$ per $100 \mathrm{ml}$ he is probably homozygously normal, since with 99 per cent certainty, 10 per cent or less of the heterozygote population has a measurement of above $43.2 \mathrm{mg}$ per $100 \mathrm{ml}$.

Using both the ratio and the ceruloplasmin concentration, we classified 45 asymptomatic members of families in which at least one case of Wilson's disease existed (Table IV). By means of the ratio, 26 of these 45 individuals could be classified with 99 per cent confidence : 19 heterozygotes and 7 homozygously normal individuals. Nineteen could not be put into either group with confidence. By means of serum ceruloplasmin concentrations, however, only 14 of these 45 individuals could be classified with the same degree of confidence: all 14 were classified heterozygotes, 13 of whom were so classified by the ratio. We concluded, therefore, that the ratio is a more sensitive criterion by which to classify individuals than the concentration of serum ceruloplasmin.

Of what clinical value is this test? It may be useful in determining whether parents, one of whom is known to be a relative of a patient with Wilson's disease, may be capable of producing offspring in whom Wilson's disease can develop. Where the results of the test are reasonably conclusive as defined above, in both parents, there can be considerable confidence concerning the genotypes of their children. For example, if an individual and his mate are both found to have test ratios of less than 0.559 , then the probability that both are normal is 0.01 , or less. If both are, in fact, heterozygotes, each child has one chance in four of being homozygous for the Wilson's disease gene and developing Wilson's disease, two chances in four of being a heterozygous carrier, and one chance in four of being homozygously normal.

This test cannot distinguish the heterozygous individual for the Wilson's disease gene from the homozygous patient because of considerable overlap in the test ratios of the two groups (Tables II and III). But such a distinction is generally not difficult to make on other grounds, as already discussed. Occasionally a heterozygous individual like M.D., whose serum concentration of ceruloplasmin is as low as that of a patient with Wilson's disease, will be seen in early life $(34,37)$. In such a case measurements of cupriuria, and of the serum concentration of non-ceruloplasmin copper, and analysis of a biopsy specimen of liver for copper may be the only ways to determine whether he is heterozygous or homozygous for the Wilson's disease gene (12). The distinction is not academic since, in the latter case, he should almost certainly receive treatment (37).

$B$. Physiological chemistry. In addition to the four abnormalities in copper metabolism associated with the homozygous state for the Wilson's disease gene, patients with this disease also exhibit an almost complete absence of incorporation of radioactive $\mathrm{Cu}^{64}$ into ceruloplasmin (Table II) $(18,25-28)$. This must be largely a consequence of their marked deficiency of ceruloplasmin. But diminished incorporation is not necessarily due only to deficiency of ceruloplasmin, since the test described in this paper shows that heterozygotes, who generally have a normal concentration of ceruloplasmin, nevertheless have a diminished incorporation of ingested $\mathrm{Cu}^{64}$ into the protein.

Three mechanisms could account for these observations in heterozygotes. First, increased copper stores might dilute the $\mathrm{Cu}^{64}$ and lower the specific activity of the copper incorporated into 
ceruloplasmin. Unfortunately, there are no data concerning the concentration of tissue copper in heterozygotes.

Second, if radioactive $\mathrm{Cu}^{64}$ is incorporated in vivo into already synthesized ceruloplasmin by exchange with ceruloplasmin copper, a diminished rate of exchange would lead to a diminished incorporation of $\mathrm{Cu}^{64}$. Such exchange has been demonstrated in vitro (32), but it has never been shown to occur in vivo. Furthermore, what evidence there is suggests that in vivo exchange does not occur (38), so that incorporation of copper probably occurs only when ceruloplasmin is synthesized.

Third, the hereditary deficiency of ceruloplasmin found in patients with Wilson's disease is very probably due to a lowered synthetic rate of the protein (39). In the heterozygotes, however, the synthesis of ceruloplasmin is not likely to be significantly impaired quantitatively because of their unusually normal concentration of the protein, unless a longer than normal half-life of the protein is combined with a diminished synthetic rate. It is difficult to conceive of a heterozygote synthesizing and destroying normal ceruloplasmin at diminished rates, both of which would be necessary, in the absence of other factors, to produce a normal concentration of the protein and a diminished rate of $\mathrm{Cu}^{64}$ incorporation into it. A simultaneous decrease in both rates is perhaps easier to imagine if the Wilson's disease gene directs the synthesis of an abnormal ceruloplasmin, since there is cogent evidence that abnormal hemoglobins are synthesized, if not destroyed, more slowly than the normal protein (40), and several varieties of human ceruloplasmin have already been described (41). But in the absence of gene interaction such a mechanism would be difficult to reconcile with the marked deficiency of ceruloplasmin exhibited by the homozygote, cc.

Clearly there is, as yet, insufficient evidence to decide if any, or a combination, of these mechanisms is the basis for the lowered incorporation of $\mathrm{Cu}^{64}$ into ceruloplasmin by heterozygotes. The observation itself, however, seems to provide another instance wherein the presence of a single gene may be manifest biochemically.

\section{SUM MARY}

1. A quantitative measure of the incorporation of $\mathrm{Cu}^{64}$ into the plasma copper-protein, cerulo- plasmin, is the ratio of the concentration of $\mathrm{Cu}^{64}$ in serum at 48 hours, to that at 1 or 2 hours, after oral ingestion of $2 \mathrm{mg}$ of copper ${ }^{64}$.

2. In 19 control subjects (homozygous for a normal gene, C), 7 patients with Wilson's disease (homozygous for an abnormal gene, c), and 19 parents of such patients (heterozygous for each gene, $\mathrm{Cc}$ ), the geometric means of these ratios were, respectively, $1.372,0.171$ and 0.510 .

3. Statistical analysis of these results indicates that this ratio is a fairly reliable means of distinguishing the heterozygous carrier of the Wilson's disease gene, c, from the individual who is homozygous for its normal allele, $\mathrm{C}$.

\section{ACKNOWLEDGMENTS}

We thank Dr. Philip Levine, Ortho Research Foundation, for determining the blood types on all subjects. We are indebted to Drs. Norman Ertel and Winfrey Goldman as well as to Miss Donna Pusateri for obtaining blood samples, and to Sister Mary Mechtilde, Administrator, for putting the facilities of Kenmore Mercy Hospital at our disposal. Dr. John W. Fertig gave generously of his time and advice in the statistical analysis of our results.

\section{REFERENCES}

1. Wilson, S. A. K. Progressive lenticular degeneration; a familial nervous disease associated with cirrhosis of the liver. Brain 1911-1912, 34, 295.

2. Hall, H. C. La Dégénérescence Hépato-lenticulaire; Maladie de Wilson, Pseudo-sclérose. Paris, Masson, 1921.

3. Bearn, A. G. Genetic and biochemical aspects of Wilson's disease. Amer. J. Med. 1953, 15, 442.

4. Bearn, A. G. Genetical studies on 32 patients with Wilson's disease. Ann. hum. Genet. 1960, 24, 33.

5. Scheinberg, I. H., and Gitlin, D. Deficiency of ceruloplasmin in patients with hepatolenticular degeneration (Wilson's disease). Science 1952, 116, 484.

6. Cartwright, G. E., Hodges, R. E., Gubler, C. J., Mahoney, J. P., Daum, K., Wintrobe, M. M., and Bean, W. B. Studies on copper metabolism. XIII. Hepatolenticular degeneration. J. clin. Invest. 1954, 33, 1487.

7. Cartwright, G. E., Markowitz, H., Shields, G. S., and Wintrobe, M. M. Studies on copper metabolism. XXIX. A critical analysis of serum copper and ceruloplasmin concentrations in normal subjects, patients with Wilson's disease and relatives of patients with Wilson's disease. Amer. J. Med. 1960, 28, 555.

8. Haurowitz, F. Über eine Anomalie des Kupferstoffwechsels. Hoppe-Seylers Z. physiol. Chem. 1930, 190, 72. 
9. Lüthy, F. Über die hepato-lentikuläre Degeneration (Wilson-Westphal-Strumpell). Dtsch. Z. Nervenheilk. 1931-32, 123, 101.

10. Glazebrook, A. J. Wilson's disease. Edinb. med. J. 1945, 52, 83.

11. Bickel, H., Neale, F. C., and Hall, G. A clinical and biochemical study of hepatolenticular degeneration (Wilson's disease). Quart. J. Med. 1957, 26, 527.

12. Scheinberg, I. H., and Sternlieb, I. The liver in Wilson's disease. Gastroenterology 1959, 37, 550.

13. Cumings, J. N. Heavy Metals and the Brain. Springfield, Ill., Charles C Thomas, 1959.

14. Mandelbrote, B. M., Stanier, M. W., Thompson, R. H. S., and Thruston, M. N. Studies on copper metabolism in demyelinating diseases of the central nervous system. Brain 1948, 71, 212.

15. Walshe, J. M. Current views on the pathogenesis and treatment of Wilson's disease. A. M. A. Arch. intern. Med. 1959, 103, 155.

16. Scheinberg, I. H., and Sternlieb, I. The pathogenesis and clinical significance of the liver disease in hepatolenticular degeneration (Wilson's disease). Med. Clin. N. Amer. 1960, 44, 665.

17. Heuyer, G., Baudoin, A., Azima, H., Faure, H., Jérome, H., and Schmitt, H. A propos de la maladie de Wilson. (Investigations généalogiques, cliniques, métaboliques portant sur $60 \mathrm{mem}$ bres d'une famille.) Rev. neurol. 1953, 89, 165.

18. Jensen, W. N., and Kamin, H. Copper transport and excretion in normal subjects and in patients with Laennec's cirrhosis and Wilson's disease: A study with $\mathrm{Cu}^{\text {st4 }}$. J. Lab. clin. Med. 1957, 49, 200.

19. Neale, F. C., and Fischer-Williams, M. Copper metabolism in normal adults and in clinically normal relatives of patients with Wilson's disease. J. clin. Path. 1958, 11, 441.

20. de Grouchy, J. Electrophorèse de sérums humains à travers gel d'amidon et identification de la céruloplasmine, chez de sujets normaux ainsi que chez des sujets homozygotes et hétérozygotes pour le gène de la maladie de Wilson. Rev. franç. Et. clin. biol. 1958, 3, 621.

21. Sass-Kortsak, A., Glatt, B. S., Leeming, J. M., and Muir, F. A. A study of heterozygosity in Wilson's disease (abstract). A. M. A. J. Dis. Child. 1959, 98, 631.

22. Hsia, D. Y-Y. Medical genetics. New Engl. J. Med. 1960, 262, 1172.

23. Pauling, L., Itano, H. A., Singer, S. J., and Wells, I. C. Sickle cell anemia, a molecular disease. Science 1949, 110, 543.

24. Earl, C. J., Moulton, M. J., and Selverstone, B. Metabolism of copper in Wilson's disease and in normal subjects. Studies with $\mathrm{Cu}-64$. Amer. J. Med. 1954, 17, 205.

25. Bearn, A. G., and Kunkel, H. G. Metabolic studies in Wilson's disease using $\mathrm{Cu}^{\text {o4 }}$. J. Lab. clin. Med. $1955,45,623$.
26. Bush, J. A., Mahoney, J. P., Markowitz, H., Gubler, C. J., Cartwright, G. E., and Wintrobe, M. M. Studies on copper metabolism. XVI. Radioactive copper studies in normal subjects and in patients with hepatolenticular degeneration. J. clin. Invest. 1955, 34, 1766.

27. Sternlieb, I., Morell, A. G., and Scheinberg, I. H. The effect of intravenously administered ceruloplasmin on copper absorption in a patient with Wilson's disease (abstract). J. clin. Invest. 1958, 37, 934.

28. Sass-Kortsak, A., Cherniak, M., Geiger, D. W., and Slater, R. J. Observations on ceruloplasmin in Wilson's disease. J. clin. Invest. 1959, 38, 1672.

29. Bearn, A. G. Wilson's disease: Is the primary inherited defect one of copper or amino acid metabolism? In Proceedings of the First International Congress of Human Genetics. Copenhagen, 1956, part IV, p. 177.

30. Sternlieb, I., Morell, A. G., and Scheinberg, I. H. Detection of the heterozygous carrier of the Wilson's disease gene (abstract). J. clin. Invest. 1959, 38, 1046.

31. Way, K., King, R. W., McGinnis, C. L., and van Lieshout, R. Nuclear level schemes. A=40$A=92$. Washington, D. C., National Academy of Sciences, National Research Council, 1955.

32. Scheinberg, I. H., and Morell, A. G. Exchange of ceruloplasmin copper with ionic $\mathrm{Cu}^{\text {es }}$ with reference to Wilson's disease. J. clin. Invest. 1957, 36, 1193.

33. Scheinberg, I. H., and Sternlieb, I. Copper metabolism. Pharmacol. Rev. 1960, 12, 355.

34. Aisen, P., Schorr, J. B., Morell, A. G., Gold, R. Z., and Scheinberg, I. H. A rapid screening test for deficiency of plasma ceruloplasmin and its value in the diagnosis of Wilson's disease. Amer. J. Med. 1960, 28, 550.

35. Ravin, H. A. Rapid test for hepatolenticular degeneration. Lancet 1956, I, 726.

36. Dixon, W. J., and Massey, F. J. Introduction to Statistical Analysis, 2nd ed. New York, McGrawHill, 1957, chapters 9 and 10.

37. Scheinberg, I. H., and Sternlieb, I. The long term management of hepatolenticular degeneration (Wilson's disease). Amer. J. Med. 1960, 29, 316.

38. Sternlieb, I., Tucker, W. D., Greene, M. W., Morell, A. G., and Scheinberg, I. H. Studies with $\mathrm{Cu}^{67}$ labeled ceruloplasmin. Clin. Res. 1960, 8, 372.

39. Scheinberg, I. H., Harris, R. S., Morell, A. G., and Dubin, D. Some aspects of the relation of ceruloplasmin to Wilson's disease. Neurology 1958, 8, suppl. 1, 44.

40. Ingram, V. M., and Stretton, A. O. M. Genetic basis of the thalassaemia diseases. Nature (Lond.) 1959, 184, 1903.

41. Morell, A. G., and Scheinberg, I. H. Heterogeneity of human ceruloplasmin. Science 1960, 131, 930. 